\title{
40S Ribosomal Protein S20
}

National Cancer Institute

\section{Source}

National Cancer Institute. 40S Ribosomal Protein S20. NCI Thesaurus. Code C152007.

$40 \mathrm{~S}$ ribosomal protein S20 (119 aa, $\sim 13 \mathrm{kDa}$ ) is encoded by the human RPS20 gene. This protein is involved in mRNA catabolism and protein synthesis. 